\title{
AWARENESS AND KNOWLEDGE OF HALITOSIS AMONG GENERAL POPULATION - A CROSS-SECTIONAL STUDY
}

\author{
Dr.Vinita Mary.A, Dr. Kesavan. R, Dr. Aruna.C, Dr. Ashwini. R, Dr. Arunkumar.T.M, \\ Dr. Mohammed Azarutheen \\ Department of Public Health Dentistry, Thai Moogambigai Dental College and Hospital, \\ Chennai, Tamil Nadu, India.
}

\section{To access $\&$ cite this article}

Website: jidam.idamadras.com

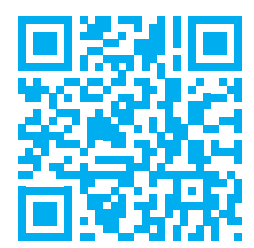

DOI:10.37841/jidam_2020_V7_I4_01

\section{Address for Correspondence:}

Dr. Aruna.C, B.D.S., Junior Resident, Department of Public Health Dentistry, Thai Moogambigai Dental College and Hospital, Chennai, Tamil Nadu, India

Email id: arunaachandrasekar98@ gmail.com

$\begin{array}{ll}\text { Received } & : 17.10 .20 \\ \text { Accepted } & : 11.11 .20 \\ \text { Published } & : 27.12 .20\end{array}$

\section{ABSTRACT}

BACKGROUND: Halitosis or Oral malodor is defined as an unpleasant breath odor and it is an important dental problem in which the affected are not conscious of it, and it also causes individuals to lose self-confidence and thus affecting their social life. It can also be because of underlying systemic condition but most prominently it is due to improper maintenance of oral hygiene.

AIM: The study aims at assessing awareness and knowledge of halitosis among general population and their perception of it.

METHODS AND MATERIALS: A descriptive cross-sectional study was conducted among 512 individuals of age 18-70 years through online forums due to COVID 19 pandemic situation. A pre-validated questionnaire with 22 closed ended question on Google forms were circulated on social media platforms like WhatsApp, Messenger and Instagram. The collected data was subjected to statistical analysis.

RESULTS: It was observed that $66 \%$ believed that halitosis was related to oral hygiene and $68 \%$ believed that smoking and alcohol consumption caused bad breath and $60 \%$ agreed that tongue coating and food lodgment caused halitosis. About $64.6 \%$ stated that bad breath affected their social life by reducing their self-confidence.

CONCLUSION: Halitosis is the one of the unattractive aspects affecting psychosocial interaction and relationship, it needs multiple approach to treat. The result of the study indicates that awareness of halitosis among general population is very high whereas knowledge on prevention of halitosis is comparatively less.

KEY WORDS: Halitosis, Bad breath, oral hygiene measures, oral malodor, social life 


\section{INTRODUCTION:}

Halitosis is the term used to define an unpleasant or offensive odour in expired air, regardless of whether it originates from oral or non-oral sources ${ }^{1}$. Microbial degradation in the oral cavity is the main cause of oral malodour ${ }^{2}$. Oral malodour or halitosis refers to unpleasant breath ${ }^{3}$

Halitosis result from the release of volatile sulfur compound ( $\mathrm{vsc}_{\mathrm{s}}$ ) through putrefactive activities of predominantly anaerobic gram-negative oral organisms ${ }^{(3)}$. In $90 \%$ of the cases, the causative factor is located in the mouth such us deep caries lesion, periodontal disease, oral infection, pericoronitis, mucosal ulceration, food impaction, reduced salivary flow, coated tongue and systemic diseases like diabetic mellitus ${ }^{4}$. Oral manifestation of diabetes includes periodontal diseases, oral candidiasis and dry mouth. Extraoral causes of halitosis could be disturbances in upper and lower respiratory tract, metabolic diseases, medications, carcinoma, etc. ${ }^{5}$

Halitosis can cause major social impact on those who suffer from it affecting their daily life causing embarrassment, reduced employment and decreasing quality of life ${ }^{6}$. Also, habits like smoking, tobacco use, alcohol, etc can trigger halitosis ${ }^{7}$.

A number of methods have been used to detect the presence of halitosis either directly or indirectly. Direct tests are organoleptic, gas chromatography and indirectly it can be assessed by odour producing microorganism or assessing their byproducts invitro ${ }^{7}$ and the BANA (N-benzoyl-DL-arginine-2napthylamide) test which uses of chemical sensors ${ }^{6}$. Oral breath can be improved by scaling and root planing and rinsing with chlorhexidine, essential oils, chlordioxide, triclosan, amine-fluoride, $\mathrm{H}_{2} \mathrm{O}_{2}$, toothpaste containing stannous fluoride, zinc or triclosan ${ }^{2}$.

The aim and purpose of this study was to access the awareness and knowledge of halitosis and individuals' attitude towards it.

\section{MATERIALS AND METHODS:}

\section{STUDY SAMPLES:}

A cross sectional study was conducted among individuals aged 18 years and above in India. Due to COVID-19 pandemic situation the study was conducted using online platforms. A self-administered pre-validated questionnaire was used to assess the knowledge and awareness about halitosis. A pilot study was conducted to validate the questionnaire using 20 samples from the study population. The internal consistency of the questionnaire was adequate (Cronbach's alpha $=0.70$ ) and reliability was assessed by test-retest and Kappa statistic and the agreement was good (0.80). The face and content validity of the questionnaire was carried out by a panel of experts who assessed whether the questionnaire items are adequately measuring the concept intended to assess, and whether the items are adequate to measure the domain of interest. The first part of the questionnaire collected demographic data of participants including socio economic status. The second part of the questionnaire consisted of substantive questions exploring respondent's selfperception and awareness of halitosis along with their knowledge about causes and management of halitosis. The questionnaire was prepared on Google forms and circulated through social media applications such as WhatsApp, Messenger and Instagram. The rationale and purpose of the study was explained as an introductory paragraph on the Google forms and the participants were assured that the data identifying the individual will be kept confidential and the collected data will be used only for research purpose. The total time taken by the participants to complete the questionnaire was 5-6 minutes approximately. The link was kept open for a period of 2 months, starting from $19^{\text {th }}$ May 2020 to $18^{\text {th }}$ July 2020 and Google form limiter was used to avoid multiple responses by an individual. All the individuals who responded the forms were included in the study.

\section{STATISTICAL ANALYSIS:}

The data was analyzed using Statistical Package for Social Sciences, IBM Corporation, SPSS Inc., Chicago, IL, USA version 21 software package (SPSS). Descriptive statistics with frequency, percentage, mean and standard deviation was computed. Pearson chi-square test was used to assess the statistical significance between genders and the $\mathrm{p} \leq 0.05$ is set as stastically significant.

\section{RESULTS:}

This study was conducted to evaluate the awareness of halitosis among general population to determine their knowledge. A total of 512 individuals 
had responded to the questionnaire during the study period.

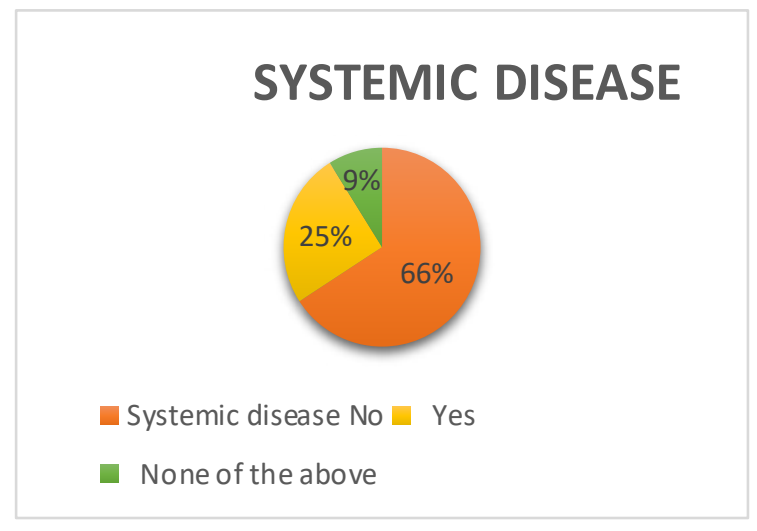

\section{GENDER}

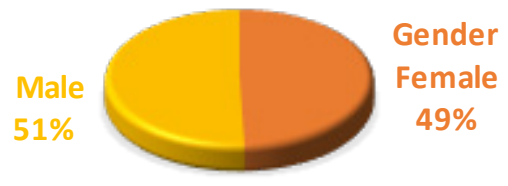

The age of the participants ranged from 18 to 70 years (Mean-36.94+8.436) and $253(49.4 \%)$ were females and $259(50.6 \%)$ were males. About $66 \%$ of the participants had stated that they had no systemic diseases, and about 59 (11.5\%) and 67 (13.1\%) had the habit of smoking and alcohol consumption, respectively.

When asked about "whether bad breath was related to oral hygiene", $66 \%$ believed that it was related to oral hygiene and $63.7 \%$ of the participants believed that proper brushing and mouthwash will reduce bad breath. When questioned about "whether smoking and alcohol consumption can cause bad breath", most of the participants responded positively and about $68.2 \%$ believed that those habits may cause bad breath. Most of the participants, $61.7 \%$ agreed that systemic diseases can cause bad breath.

Among the participants, $62.1 \%$ of the participants thought food lodgments in teeth could cause bad breath and $58.2 \%$ of participants believed food particles coating on tongue caused bad breath.

Majority of the participants, $52.9 \%$ responded that all of the mentioned options (i.e. oral infection, dry mouth, medication) can cause halitosis followed by oral infection (20.9\%), Dry mouth (14.3\%) medication $(11.1 \%)$. Regarding the association of halitosis to stomach problems and dental caries, about $52.5 \%$ and $55.1 \%$ respectively, responded positively.

Almost $64.6 \%$ of the participants responded that bad breath reduced their confidence level in public, and about $60.7 \%$ of the participants were aware that uncleaned denture may also cause bad breath. Among $63.3 \%$ of the participants responded to "I will advise them to have proper oral hygiene" to the people experiencing halitosis.

When experience of bad breath was compared between males and females, it was observed that males had experienced bad breadth significantly more often than females, $(\mathrm{p}=0.33)$ and significantly a greater number of males had approached dentists for treating bad breadth. It was observed that significantly a greater number of females responded

TABLE 1: Distribution of participants according to knowledge and attitude towards halitosis

\begin{tabular}{|l|l|l|l|}
\hline QUESTION & OPTION & FREQUENCY & PERCENT \\
\hline \multirow{2}{*}{$\begin{array}{l}\text { Have you ever experienced bad } \\
\text { breath? }\end{array}$} & Yes & 203 & 39.6 \\
\cline { 2 - 4 } & No & 192 & 37.5 \\
\cline { 2 - 4 } & Sometimes & 117 & 22.9 \\
\hline
\end{tabular}




\begin{tabular}{|c|c|c|c|}
\hline \multirow{3}{*}{$\begin{array}{l}\text { Do you think BAD BREATH is } \\
\text { related to oral hygiene? }\end{array}$} & Yes & 338 & 66.0 \\
\hline & No & 65 & 12.7 \\
\hline & Maybe & 107 & 20.9 \\
\hline \multirow{3}{*}{$\begin{array}{l}\text { Do you think proper brushing and } \\
\text { usage of mouth wash will reduce } \\
\text { BAD BREATH? }\end{array}$} & Yes & 326 & 63.7 \\
\hline & No & 76 & 14.8 \\
\hline & Maybe & 110 & 21.5 \\
\hline \multirow{3}{*}{$\begin{array}{l}\text { Do you think smoking /alcohol } \\
\text { consumption can cause bad breath? }\end{array}$} & Yes & 349 & 68.2 \\
\hline & No & 73 & 14.3 \\
\hline & Maybe & 90 & 17.6 \\
\hline \multirow{3}{*}{$\begin{array}{l}\text { Do you think BAD BREATH can } \\
\text { occur due to systemic diseases like } \\
\text { diabetes, liver disorder, gastric } \\
\text { problem, etc? }\end{array}$} & Yes & 316 & 61.7 \\
\hline & No & 61 & 11.9 \\
\hline & Maybe & 135 & 26.4 \\
\hline \multirow{3}{*}{$\begin{array}{l}\text { Do you think food lodgement in } \\
\text { teeth can cause BAD BREATH? }\end{array}$} & Yes & 318 & 62.1 \\
\hline & No & 85 & 16.6 \\
\hline & Maybe & 109 & 21.3 \\
\hline \multirow{3}{*}{$\begin{array}{l}\text { Do you think food particles } \\
\text { coating on tongue can cause BAD } \\
\text { BREATH? }\end{array}$} & Yes & 298 & 58.2 \\
\hline & No & 73 & 14.3 \\
\hline & Maybe & 137 & 26.8 \\
\hline
\end{tabular}




\begin{tabular}{|c|c|c|c|}
\hline \multirow{8}{*}{$\begin{array}{l}\text { According to you, BAD BREATH } \\
\text { can be due to }\end{array}$} & Dry mouth & 73 & 14.3 \\
\hline & $\begin{array}{l}\text { Improper } \\
\text { digestion }\end{array}$ & 1 & .2 \\
\hline & $\begin{array}{l}\text { Internal } \\
\text { infection } \\
\text { in throat or } \\
\text { somewhere }\end{array}$ & 1 & .2 \\
\hline & Medication & 57 & 11.1 \\
\hline & Normal & 1 & .2 \\
\hline & Oral infection & 107 & 20.9 \\
\hline & $\begin{array}{l}\text { Spicy foods } \\
\text { and ulcers }\end{array}$ & 1 & .2 \\
\hline & $\begin{array}{l}\text { All of the } \\
\text { above }\end{array}$ & 271 & 52.9 \\
\hline \multirow{3}{*}{$\begin{array}{l}\text { Do you think BAD BREATH } \\
\text { predominantly occurs among elderly } \\
\text { persons? }\end{array}$} & Yes & 245 & 47.9 \\
\hline & No & 112 & 21.9 \\
\hline & Maybe & 148 & 28.9 \\
\hline \multirow{3}{*}{$\begin{array}{l}\text { Do you think BAD BREATH can be } \\
\text { caused from stomach problems? }\end{array}$} & Yes & 269 & 52.5 \\
\hline & No & 102 & 19.9 \\
\hline & Maybe & 141 & 27.5 \\
\hline \multirow{3}{*}{$\begin{array}{l}\text { Do you think BAD BREATH can } \\
\text { occur due to dental caries? }\end{array}$} & Yes & 282 & 55.1 \\
\hline & No & 98 & 19.1 \\
\hline & Maybe & 135 & 25.8 \\
\hline \multirow{3}{*}{$\begin{array}{l}\text { Do you think drinking plenty of } \\
\text { water can reduce BAD BREATH? }\end{array}$} & Yes & 271 & 52.9 \\
\hline & No & 89 & 17.4 \\
\hline & Maybe & 152 & 52.9 \\
\hline
\end{tabular}




\begin{tabular}{|c|c|c|c|}
\hline \multirow{3}{*}{$\begin{array}{l}\text { Do you think BAD BREATH can } \\
\text { occur in a healthy individual also? }\end{array}$} & Yes & 283 & 55.3 \\
\hline & No & 91 & 17.8 \\
\hline & Maybe & 129 & 25.2 \\
\hline \multirow{4}{*}{$\begin{array}{l}\text { According to you, what measures } \\
\text { can prevent BAD BREATH? }\end{array}$} & Brush & 70 & 13.7 \\
\hline & Floss & 51 & 10.0 \\
\hline & $\begin{array}{l}\text { Mouthwash } \\
\text { and mouth } \\
\text { fresheners }\end{array}$ & 133 & 26.0 \\
\hline & $\begin{array}{l}\text { All of the } \\
\text { above }\end{array}$ & 258 & 50.4 \\
\hline \multirow{3}{*}{$\begin{array}{l}\text { Have you ever approached a dentist } \\
\text { for treating BAD BREATH? }\end{array}$} & Yes & 166 & 32.4 \\
\hline & No & 261 & 51.0 \\
\hline & Maybe & 74 & 14.5 \\
\hline \multirow{3}{*}{$\begin{array}{l}\text { Do you think BAD BREATH can } \\
\text { decrease confidence level in the } \\
\text { individual? }\end{array}$} & Yes & 331 & 64.6 \\
\hline & No & 76 & 14.8 \\
\hline & Maybe & 105 & 20.5 \\
\hline \multirow{3}{*}{$\begin{array}{l}\text { Do you think having good nutrition } \\
\text { can reduce BAD BREATH? }\end{array}$} & Yes $J / D A$ & 277 & 54.1 \\
\hline & No & 73 & 14.3 \\
\hline & Maybe & 153 & 29.9 \\
\hline \multirow{4}{*}{$\begin{array}{l}\text { According to you, at what interval } \\
\text { can an individual experience BAD } \\
\text { BREATH? }\end{array}$} & Daily & 117 & 22.9 \\
\hline & Early morning & 157 & 30.7 \\
\hline & $\begin{array}{l}\text { Once in a } \\
\text { week }\end{array}$ & 89 & 17.4 \\
\hline & No idea & 149 & 29.1 \\
\hline
\end{tabular}




\begin{tabular}{|c|c|c|c|}
\hline \multirow{3}{*}{$\begin{array}{l}\text { Do you think BAD BREATH might } \\
\text { be due to gum disease? }\end{array}$} & Yes & 243 & 47.5 \\
\hline & No & 108 & 21.1 \\
\hline & Maybe & 161 & 31.4 \\
\hline \multirow{3}{*}{$\begin{array}{l}\text { Are you aware of any device to } \\
\text { measure BAD BREATH? }\end{array}$} & Yes & 205 & 40.0 \\
\hline & No & 197 & 38.5 \\
\hline & Maybe & 104 & 20.3 \\
\hline \multirow{3}{*}{$\begin{array}{l}\text { Do you think that Uncleaned } \\
\text { dentures can cause BAD BREATH? }\end{array}$} & Maybe & 311 & 60.7 \\
\hline & No & 83 & 16.2 \\
\hline & Yes & 1 & 23.0 \\
\hline \multirow{5}{*}{$\begin{array}{l}\text { What is your opinion of people with } \\
\text { BAD BREATH? }\end{array}$} & I will advise & 324 & 63.3 \\
\hline & $\begin{array}{l}\text { them to have } \\
\text { proper oral } \\
\text { hygiene }\end{array}$ & & \\
\hline & $\begin{array}{l}\text { I will continue } \\
\text { to be friendly } \\
\text { with them }\end{array}$ & 72 & 14.1 \\
\hline & $\begin{array}{l}\text { I will ignore } \\
\text { them }\end{array}$ & 66 & 12.9 \\
\hline & $\begin{array}{l}\text { None of the } \\
\text { above }\end{array}$ & 50 & 9.8 \\
\hline
\end{tabular}


Table 2. Comparison of gender according to knowledge and attitude towards halitosis

\begin{tabular}{|c|c|c|c|c|}
\hline \multirow[t]{2}{*}{ QUESTION } & \multirow[t]{2}{*}{ OPTION } & \multicolumn{2}{|l|}{ Gender } & p-value* \\
\hline & & Male & Female & \multirow{4}{*}{0.033} \\
\hline \multirow{3}{*}{$\begin{array}{l}\text { Have you ever } \\
\text { experienced bad } \\
\text { breath? }\end{array}$} & Yes & $110(21.5 \%)$ & $93(18.2 \%)$ & \\
\hline & No & $83(16.2 \%)$ & $109(21.3 \%)$ & \\
\hline & Maybe & $66(12.9 \%)$ & $51(10.0 \%)$ & \\
\hline \multirow{3}{*}{$\begin{array}{l}\text { Have you ever } \\
\text { approached a dentist } \\
\text { for treating BAD } \\
\text { BREATH? }\end{array}$} & Yes & $91(17.8 \%)$ & $75(14.6 \%)$ & \multirow{3}{*}{0.000} \\
\hline & No & $114(22.3 \%)$ & $147(28.7 \%)$ & \\
\hline & Maybe & $51(10.0 \%)$ & $23(4.5 \%)$ & \\
\hline \multirow[t]{4}{*}{$\begin{array}{l}\text { What is your } \\
\text { opinion of people } \\
\text { with BAD BREATH }\end{array}$} & $\begin{array}{l}\text { I will advise } \\
\text { them to have } \\
\text { proper oral } \\
\text { hygiene }\end{array}$ & $145(28.3 \%)$ & $\begin{array}{c}179(35.0 \%) \\
-8 \\
-\infty\end{array}$ & \multirow[t]{4}{*}{0.003} \\
\hline & $\begin{array}{l}\text { I will continue } \\
\text { to be friendly } \\
\text { with them }\end{array}$ & $39(7.6 \%)$ & $33(6.4 \%)$ & \\
\hline & $\begin{array}{l}\text { I will ignore } \\
\text { them }\end{array}$ & $44(8.6 \%)$ & $22(4.3 \%)$ & \\
\hline & $\begin{array}{l}\text { None of the } \\
\text { above }\end{array}$ & $31(6.1 \%)$ & $19(3.7 \%)$ & \\
\hline
\end{tabular}


that they would advise a person with halitosis to have proper oral hygiene.

\section{DISCUSSION:}

Oral malodour is a very common problem among entire population. Self-assessment and perception are the most important factor in both controlling and diagnosing of bad breath ${ }^{9}$. This study was undertaken to assess the knowledge and awareness of halitosis among general population.

According to the present study, prevalence and experience rate of bad breath was about $39.6 \%$ of participants which was higher compared to the study by Alshehri ${ }^{3}$ (39\%) and lower when compared to the study by Fadhil et al ${ }^{12}$ in which it was estimated to be around $50 \%$.

Halitosis can be predominantly reduced by oral hygiene measures and in the current study overall $66 \%$ believed that bad breath was related to oral hygiene. On contrary it was lower when the present study was compared to study by Yoko et al ${ }^{11}$ (78.4\%); higher when compared to study by Settineri et $\mathrm{al}^{8}(29.6 \%)$. The difference might be because most of the individual in the present study were aware of oral hygiene measures.

It is advocated that regular brushing twice a day and mouth rinsing contributes to good oral hygiene. In present study, about $63.7 \%$ of the participants agreed to it. On the contrary, in a study conducted by Azizah et $a l^{10}$ a greater number of the subjects, $77 \%$ believed that oral hygiene measures prevented halitosis.

In the present study, 282 participants (55\%) agreed that bad breath can occur due to dental caries and $107(20.9 \%)$ of participants agreed that bad breath can occur due to oral infections. Whereas in the survey conducted by Bader et $\mathrm{al}^{6}$, in Saudi Arabia in 2017 revealed that $64.6 \%$ of participants agreed that presence of dental caries was one of the reasons for halitosis and $79.4 \%$ of participants agreed that halitosis was due to intra oral sources. The percentage of participants who agreed that halitosis was due to dental caries and oral infection was high compared to the present survey. This may be because the participants were more aware about factors leading to dental caries.
The status of having other medical problems was found to be significantly associated with occurrence of long-standing breath malodor ${ }^{15}$, with regards to this in the present study $61.7 \%$ of the respondents agreed that systemic diseases like diabetes, liver disorder and gastric problem contributed to bad breath.

In the present study, tongue coating causing bad breath was mentioned by about $58.2 \%$ of the respondents which was higher compared to study conducted by Azizah et $\mathrm{al}^{10}(34.4 \%)$ and similar to the study by Badar $A^{6}(57 \%)$. The possible explanation for this might be as pointed by De Boever and Loerche that uncleaned tongue is usually harbouring periodontal bacteria such as prevotella intermedia, porphyromnas gingivalis and fusobacterium that were responsible for producing volatile sulphur compounds that accounts for oral malodor from the mentioned ${ }^{15}$.

Among the participants, about 52.5\% answered that stomach problem could also be the reason for halitosis which was in accordance with the study conducted by Nabila et $\mathrm{al}^{13}(59 \%)$ but lower from a study by Azizah et al $(44.6 \%)^{10}$ Also, participants believed that medical condition such as dry mouth (14.3\%) and medications (11.1\%) could be the etiology and contributing factor. On the other hand, in the study by Azizah et $\mathrm{al}^{10}$, it was higher, $31.4 \%$ for dry mouth and in the study by Settineri et $\mathrm{al}^{8}, 40 \%$ of the respondents answered that taking medications such as immunosuppressant's like cyclosporine, tacrolimus and calcium channel blockers like amlodipine, diltiazem could cause halitosis.

The participants approaching dentists for bad breath was $32.4 \%$ in the current study. On contrary, study findings by Nabila et al ${ }^{13} 82.4 \%$ of the respondents as agreed on seeking dentist opinion. This disparity may be due to lack of knowledge about treatment and prevention of halitosis in current study individuals.

Most of the participants in the present study i.e. about $64.6 \%$ agreed that bad breath reduced their social life, but in the study by Badar A et al ${ }^{(6)}$, only $36.3 \%$ responded so, whereas it was higher in a study by Nabila et $\mathrm{a}^{13}(71 \%)$. This implies that halitosis can psychologically affects individuals' social life. 
Gum disease like bleeding gums while brushing and other periodontal problem like periodontal plaque and pocket also have impact on halitosis. In the present study, $47.5 \%$ of the participants agreed to it, and it was similar to a study by Rana et $\mathrm{al}^{9}$, where $47.78 \%$ of males agreed so.

The limitation of the present study is that it relies only on self-perceived data, and no clinical examination was performed to assess the actual presence of halitosis.

In this survey, the participants seem to have appropriate perception on causes of halitosis whereas the knowledge of precautionary measures to prevent it was comparatively low. This disparity can be overcome by more feasible methods to assess bad breath and imparting knowledge about ways to prevent it among the population.

\section{CONCLUSION:}

Halitosis is the one of the unattractive aspects affecting psychosocial interaction and relationships and it needs multiple approach to treat. Oral hygiene habits such as brushing the teeth twice daily, cleansing with mouthwash and usage of dental floss can reduce the prevalence of halitosis. The result of the study indicates that awareness of halitosis among general population was high whereas knowledge on prevention on halitosis was comparatively low. Thus, each individual in the population should be encouraged to gain knowledge about the prevention of halitosis.

FINANCIAL SUPPORT AND SPONSORSHIP:

Nil.

\section{CONFLICTS OF INTEREST:}

There are no conflicts of interest.

\section{REFERENCES:}

1. Michael M. Bornstein, Bruce L. Stocker, Rainier Sumann, Walter B. Burgin and Adrin Lussi; Prevalence of Halitosis in young male adults: A study in Swiss Army recruits comparing self-reported and clinical data, Journal of periodontology 80 (1), 24-31, 2009
2. Curd ML Bollen and Thomas Beikler, Halitosis: the multidisciplinary approach. International journal of oral science 4 (2), 5563,2012

3. Fahad Ali Alshehri; knowledge and attitude of Saudi individuals towards self-perceived halitosis. The Saudi Journal for Dental Research 7 (2), 91-95, 2016

4. Firas Q Alzoubi, Humana A Larasneh and Nidal M. Daamseh;

5. Relationship of psychological and oral health statuses with self-perceived halitosis on a Jordanian population: a cross-sectional study. BMC oral health 15 (1), 89, 2015

6. Mohammed S. Al-Zahrani, Khalid H Zawawi, Obadiah N. Austah and Hamed S. Al_Ghandi. self-reported halitosis in relation to glycated haemoglobin level in diabetic patients. The open dentistry journal 5, 154, 2011

7. Bader Alim, Afat Aljohani, Sahal Arabi, Heba Almahdi, Ghadar jemah and Zoubayda Alazhari; Knowledge and Awareness of halitosis causes among Taibah University students in Al-Medinah, Saudi Arabia, 2017. Clinical, cosmetic and investigational dentistry 9, 45, 2017

8. Mohammed M Hammad, Azmi MG Darwish, Haider Al-waeli, Bassel Tarakji and Teen T Alhadithy: Prevalence and Awareness of halitosis in a sample of Jordanian population. Journal of International Society of Preventive \& Community Dentistry 4 (Suppl 3), S178, 2014

9. Salvatore Settineri, Carmela Mentor, Simona C Gugliotta Arbra Saitta, Antonella Terranova, Giuseppe Trimarchi, Domenico Mallamare; Self-reported halitosis and emotional state: Impact on oral condition and treatment. Health and quality of life outcomes 8 (1), 34, 2010

10. Saida Rana, Asma shakoor, Ayesha Fahim; Awareness of halitosis and oral hygiene among undergraduate dental students. JPDA 26 (04), 141, 2017

11. Azizah Bin Mubayrik, Rana Al Hamdan, Emad M Al Halaq, Hamad Albagieh, Dan Al Ahmed, Hend Jaddoh, Maivadh 
Demyati, Raivan Abu Shryei; self-perception, knowledge and awareness of halitosis among female university students. Clinical, cosmetic and investigational dentistry 9, 45, 2017

12. Yoko Kawaguchi, Akiko oshoro, Ei Ei Aung, Takashi Zaitsu; Relationship of halitosis concern with oral health behaviour and knowledge among Myanmar people. Journal of dentistry open access 2019.01-03

13. Fadhil OK, Mugonzibwa.Perception on halitosis among dental patients attending muhimbili national hospital dental clinic. Tanzania dental journal Vol. 12 No. 1 (2005)

14. Nabila Ahmed Sedky, Perceived impact of halitosis on individual's social life and marital relationship in Qussim province, KSA.Journal of American Science, Journal of American Science 2015;11(3)

15. C.M. Kayombo and E.G. Mughambha, Selfreported halitosis in relation to oral hygiene practices, oral health status, general health problems and multifactorial characteristics among workers in iliala and temeke municipals, Tanzania.International journal of dentistry Int J Dent. 2017; 2017:8682010

16. Mughamba EGS, Rutaihwa RD, SelfReported, subjectively determined breath malodor, associated factors, treatment seeking behaviour and oral hygiene practices among adults in Kindondoni, Tanzania.Tanzania Dental Journal Int J Dent. 2017; 2017: 8682010. 